\title{
Krytyka genetyczna jako kulturowa poietyka (nie)pamięci
}

Mateusz Antoniuk

TEKSTY DRUGIE 2020, NR 6, S. 236-258

DOI: $10.18318 /$ td.2020.6.14 | ORCID: 0000-0002-1608-2691

\section{Krytyka genetyczna w polu nowej humanistyki}

Gdy krytyka genetyczna - w swoim paryskim wydaniu, jako critique génétique - rodziła się na przełomie lat 6o. 70. ubiegłego stulecia, była niewątpliwie w zgodzie z linią przemian literaturoznawczej sceny'. Z jednej strony pojawiała się jako wygłos strukturalizmu (co przejawiało się w ambicjach tworzenia silnego dyskursu, typologizującego i systematyzującego rzeczywistość ${ }^{2}$ a także w trosce o utrzymanie

1 Na ten temat zob. m.in. S. Jaworski „Piszę, więc jestem”: o procesie twórczym w literaturze, Universitas, Kraków 1993, s. 88-95; Z. Mitosek Teorie badań literackich, PWN, Warszawa 1995 (ostatni rozdział); L. Hay Przesłanie do uczestników konferencji "Genesis - Cracow 2019", "Wielogłos" 2019 nr 1; M. Antoniuk, "Kosmos"wzywa polskg̨ krytykę genetyczną, "Pamiętnik Literacki” 2020, z. 4 (przyp. 5).

2 Por. idealizujący model "procesu tekstotwórczego" skonstruowany przez Pierre-Marca de Biasiego na podstawie praktyki twórczej Flauberta, lecz mający ambicje uogólnienia i ekstrapolacji, wyróżniający cztery główne "fazy" wytwarzania tekstu (podzielone na subfazy) i przypisujący im określone "funkcje operacyjne" oraz typy dokumentów; zob. P.-M. de Biasi Genetyka tekstów, przeł. F. Kwiatek, M. Prussak, Wydawnictwo IBL, Warszawa 2015, s. 57-85.

\section{Mateusz Antoniuk}

- dr hab., literaturoznawca, pracuje na

Wydziale Polonistyki U), gdzie pełni funkcję kierownika Pracowni Badań nad Procesem Twórczym. Autor książek: Pracownia Herberta. Studia nad procesem tekstotwórczym (2017, współautorstwo i redakcja); Słowo raz obudzone. Poezja Czesława Miłosza: próby czytania (2015). Publikował m.in. w "Tekstach Drugich", „Ruchu Literackim”, „Przestrzeniach Teorii", "Textual Cultures". Zainteresowania: literatura polska XX wieku, krytyka genetyczna. 
dystynkcji między podmiotem operacji tekstotwórczych a biograficznym ,ja” pisarza), z drugiej zaś korelowała z tendencjami określanymi dziś mianem poststrukturalistycznych. Kiedy w 1970 roku Roland Barthes postulował „rozgwieżdżenie tekstu" (czytanie wielokrotne, ponawiane i różnicujące, odkrywające różne „wejścia" w tekst ${ }^{3}$ ), pierwsi genetycy kierowali wzrok ku brulionowym kartom, na których „dzieła” (w postaci finalnej imponujące konstrukcyjną precyzją) jawiły się jako struktury jeszcze nieustrukturyzowane $e^{4}$.

Pięćdziesiąt lat później ta późnostrukturalistyczna/wczesnopoststrukturalistyczna "geneza krytyki genezy" jest kwestią historyczną, aktualną o tyle, o ile prowokującą do pytania: jakie miejsce w pejzażu humanistyki zajmują studia nad procesem (teksto)twórczym dziś? Czy krytyka genetyczna spotyka się obecnie z najbardziej gorącymi tematami humanistycznej debaty? Mój artykuł jest próbą („brulionem”) odpowiedzi na tak postawione pytanie. Spróbuję w nim pokazać, jak krytyka genetyczna staje się współwytwórcą bardzo dziś ważnej, transdyscyplinarnej refleksji humanistycznej zwanej pamięcioznawstwem (studiami nad pamięcią). Próba będzie się opierać na analityczno-interpretacyjnej inscenizacji, sytuującej w centrum uwagi egzemplaryczny kazus.

W roli owego kazusu obsadzony zostanie wiersz będący obiektem „pamięcioznawczo gorącym", atrakcyjnym dla opisów czynionych z „wnętrza pamięcioznawstwa". Można określać go mianem tekstowego fenomenu "kultury pamięci"s czy też tekstowego „medium pamięci”. Przez badaczy

3 Por. R. Barthes S/Z, przeł. M.P. Markowski, M. Gołębiewska, Wydawnictwo KR, Warszawa 1999, S. 46.

4 Na temat konwergencji zachodzących między krytyką genetyczną a różnymi aspektami literaturoznawczej teorii i praktyki uprawianej przez Barthes'a zob. D. Ferrer Genetic Criticism in the Wake of Barthes, w: Writing the Image. After Roland Barthes, ed. J.-M. Rabaté, University of Pennsylvania Press, Philadelphia 1997, s. 217-227.

5 Pojęcie "kultury pamięci” należy do elementarnego dykcjonarza pamięcioznawstwa (przejawem tego statusu jest m.in. obecność pojęcia w studium Modi memorandi. Leksykon kultury pamięci, red. M. Saryusz-Wolska, R. Traba, Warszawa 2014). Jak wiele pojęć elementarnych, także i to bywa używane różnie. W moim szkicu rozumiem je, za Marią Kobielską, jako "splot procesualnych i dynamicznych praktyk pamiętania, znajdujących swój wyraz i narzędzie w bardzo różnych tekstach i działaniach w ramach kultury"; M. Kobielska Urządzenia do pamiętania ,"Studia Kulturoznawcze" 2017 nr 1, s. 56. Por. także nieco wcześniejszą refleksję tej samej badaczki nad rozumieniem tego terminu: M. Kobielska Polska kultura pamięci wXXI wieku: dominanty. Zbrodnia katyńska, powstanie warszawskie i stan wojenny, Wydawnictwo IBL, Warszawa 2016, s. $23-24$.

6 Pojęcie i ujęcie tekstu jako medium, czyli nośnika, ale i współproducenta pamięci (indywidualnej, zbiorowej, kulturowej...), to jeden z loci communes światowych studiów pamięcioznaw- 
zainteresowanych tematyką pamięciologiczno-literaturoznawczą wiersz ów został już zauważony: Maria Kobielska w 2016 roku wskazała go jako jeden z „emblematów” dla najbardziej aktualnych i dominujących tendencji zachodzących w polu współczesnej polskiej kultury pamięci ${ }^{7}$. Przyjrzymy się zatem wierszowi Zbigniewa Herberta pt. Wilki.

Najpierw (w części drugiej artykułu) społeczna historia Wilków jako medium pamięci opowiedziana zostanie „od początku” - to znaczy od pierwodruku wiersza - do okolic roku 2020. Następnie (w części trzeciej artykułu) pokażę, co ciekawego - także czy przede wszystkim z pamięcioznawczego punktu widzenia - wydarzy się,gdy „początek” opowieści zostanie usytuowany głębiej, tam, gdzie sięga krytyka genetyczna: w brulionie. W ten sposób będziemy mogli przetestować potencjał krytyki genetycznej jako czynnika dynamizującego badania nad związkami literatury i pamięci. Teoretycznemu uogólnieniu tak przeprowadzonego eksperymentu zostanie poświęcona część czwarta.

\section{W polu społecznej widzialności}

Wilki miały dwie premiery: prasową i tomikową. Wiersz ukazał się w 1991 roku na łamach „Czasu Krakowskiego” (numer 75, datowany 29 marca 1 kwietnia) oraz w 1992 roku na kartach tomu Rovigo.

Wilki (pierwodruk prasowy)

Ponieważ żyli prawem wilka historia o nich głucho milczy pozostał po nich w kopnym śniegu żółtawy mocz i ten ślad wilczy

szybciej niż nawet strzał zdradziecki trafiła serce mściwa rozpacz pili samogon jedli nędzę tak potrafili losom sprostać
Wilki (druk w tomiku)

Ponieważ żyli prawem wilka historia o nich głucho milczy pozostał po nich w kopnym śniegu żółtawy mocz i ten ślad wilczy

szybciej niż w plecy strzał zdradziecki trafiła serce mściwa rozpacz pili samogon jedli nędzę tak się starali losom sprostać

czych. Zob. m.in. precyzacje tego pojęcia w: A. Assmann 1998 - Między historiq̨ a pamięcią oraz A. Erll Literatura jako medium pamięci zbiorowej, w: Pamięć zbiorowa i kulturowa. Współczesna perspektywa niemiecka, przeł. i red. M. Saryusz-Wolska, Universitas, Kraków 2009; J. Tabaszewska Poetyki pamięci. Współczesna poezja wobec tradycji i pamięci, Wydawnictwo IBL, Warszawa 2016, s. 151-153, 158-161.

7 M. Kobielska Polska pamięć autoafirmacyjna, "Teksty Drugie” 2016 nr 6, s. 364. 
już nie zostanie agronomem

"Ciemny" a „Świt" - księgowym

"Marusia" - matką „Grom" - poetą

osiwia śnieg ich młode głowy

nie opłakała ich Elektra

nie pogrzebała Antygona

i będą tak przez całą wieczność

w zawszonym śniegu wiecznie konać

przegrali dom swój na Podlasiu

kędy zawiewa sypki śnieg

nie nam żałować - gryzipiórkom

i gładzić ich zmierzwioną sierść

ponieważ żyli prawem wilka

historia o nich głucho milczy

został na zawsze w sypkim śniegu

żółtawy mocz

i ten ślad wilcz już nie zostanie agronomem

"Ciemny" a „Świt" - księgowym

"Marusia" - matką „Grom" - poetą

posiwia śnieg ich młode głowy

nie opłakała ich Elektra

nie pogrzebała Antygona

i będą tak przez całą wieczność

w głębokim śniegu wiecznie konać

przegrali dom swój w białym borze kędy zawiewa sypki śnieg nie nam żałować - gryzipiórkom i gładzić ich zmierzwioną sierść

ponieważ żyli prawem wilka historia o nich głucho milczy został na zawsze w dobrym śniegu żółtawy mocz i ten trop wilczy

Różnice tekstowe są drobne, najpoważniejsza modyfikacja dokonała się na poziomie paratekstu: dedykacja prasowa - „Pamięci Oficerów, Podoficerów, Żołnierzy, którzy zginęli w lasach po roku 1945 z bronią w ręku i nie złamali przysięgi" - upamiętniała (anonimowych poległych), dedykacja tomikowa - „Marii Oberc" - honorowała (żyjącą i określoną z imienia osobę)8. Powyższe zestawienie nie pozwala jednak uchwycić poważnej różnicy zachodzącej między dwiema „premierowymi odsłonami” Wilków: otóż utwór ten prezentowany był w dwu odmiennych konsytuacjach publikacyjnych, które przydawały mu lub ujmowały znaczeń suplementarnych.

Stając się częścią gazetowej strony, wiersz wchodzi w interakcje z innymi tekstami, komunikatami niewerbalnymi, a także z czymś nieredukowalnym do jednej, tekstowej czy graficznej, reprezentacji, co określić można mianem „linii” pisma. Dynamika interakcji wiersz - gazeta bywa pasjonująca, jak o tym świadczy studium Jacka Łukasiewicza o „wierszach

8 Na temat dedykacyjnych praktyk Herberta zob. M. Urbanowski Dedykacje Herberta, w: Zbigniew Herbert i poetyka daru, red. B. Gautier, M. Urbanowski, Wydawnictwo Uniwersytetu Jagiellońskiego, Kraków 2020. 
w gazecie"9 lub praca George’a Bornsteina, skupiona wokół konceptu „polityki strony" (politics of the page) ${ }^{10}$. Właśnie z takiej perspektywy warto przyjrzeć się stronie "Czasu Krakowskiego". I dostrzec, że Wilki wchodzą tu w relację z innym wierszem Herberta, także wówczas pierwszy raz publikowanym - ze słynnym Chodasiewiczem, czyli pamfletem na Czesława Miłosza. Oba teksty zostały wyodrębnione jako dwuelementowa całość przez ujęcie ich w ramkę, opatrzenie nagłówkiem „Nowe wiersze Zbigniewa Herberta” oraz autorskim komentarzem, czyli faksymile odręcznego listu poety do redaktora: „Szanowny, Drogi Panie Kolego, załączam dwa utwory liryczne o czem [?] rozmawialiśmy przez telefon. Serdecznie dłoń ściskam - Zbigniew Herbert".

Dane do czytania jako dyptyk, dwa „nowe wiersze” aż prosiły się o lekturę „hybrydową". Na przykład taką: w Chodasiewiczu Herbert pokazuje Miłosza jako poetę wyzbytego poczucia narodowej tożsamości (kogoś, kto godzi się ze stwierdzeniem „na barkach ciąży nam ojczyzna”), w Wilkach przedstawia zaś siebie jako poetę niegodnego („nie nam żałować - gryzipiórkom”), lecz składającego hołd narodowym bohaterom. Zatem dwie biegunowo przeciwstawne postawy, wyobrażone na dwóch "skrzydłach" poetyckiego dyptyku - poeta zrywający „ze wspólnotą, z korzeniami” (w domyśle Miłosz) i poeta odnawiający pamięć wspólnoty (w domyśle Herbert). „Wilki w gazecie” (by sparafrazować formułę Łukasiewicza) stawały się w ten sposób składnikiem aluzyjnej krytyki personalnej, początkiem kampanii anty-Miłoszowej, którą Herbert kontynuował w kolejnych latach. Idźmy dalej. „Czas Krakowski” we wczesnych latach 9o. ubiegłego wieku wyrażał idee polityczne środowisk prawicowo-konserwatywnych, takie jak dekomunizacja struktur państwowych, lustracja, rozliczenie działań komunistycznego aparatu represji. Wiersz głoszący pochwałę antykomunistycznego podziemia, upominający się o „inną" pamięć historyczną, bez wątpienia wpisywał się w ten ogląd świata. Jego publikacja (wraz z przyjacielskim listem autora) eksponowała związki czasopisma i poety. W ramach (powtórzmy tym razem za Bornsteinem) „polityki strony” Wilki odgrywały rolę głosu poparcia dla politycznej i etycznej linii pisma.

9 J. Łukasiewicz Wiersze w gazetach 1945-1949, Wydawnictwo Uniwersytetu Wrocławskiego, Wrocław 1992. bridge 2001 (pol. przekład fragmentu książki: G. Bornstein Jak czytać stronę. Modernizm i materialność tekstu, przeł. J. Sobesto, przekład przejrzał i poprawił T. Kunz, „Wielogłos” 2017 nr 1, s. 7-37). 
Cały ten interpretacyjnie relewantny kontekst publikacji znikał w tomikowej inkarnacji wiersza. Wydawnictwo Dolnośląskie, które opublikowało Rovigo, nie budowało swego wizerunku na zasadzie ideowo-politycznego zaangażowania - Wilki nie wzmacniały już zatem polityki historycznej edytora. $\mathrm{Na}$ kartach tomiku nie pojawiły się też w bezpośrednim sąsiedztwie Chodasiewicza. Herbert "rozmontował” pierwotny dyptyk, włączając Wilki w inną, by tak rzec, „intertekstualność paginacyjną”: na sąsiedniej stronie ulokował korespondujący z Wilkami tematycznie (choć utrzymany w odmiennej poetyce) wiersz Ręce. Utwór ów stanowił optymistyczne dopowiedzenie: umarli nie są tu już wielkimi przemilczanymi, których możemy jedynie wspominać z poczuciem winy, stają się (dla podmiotu mówiącego) duchami opiekuńczymi.

Tak oto już u początku społecznej egzystencji wiersz wykazał się labilnością i mobilnością: skonkretyzowany w dwu odmianach tekstowych, przemieszczający się między różnymi kontekstami interpretacyjnymi, perspektywami odbioru, wspólnotami czytelniczymi, był już właściwie „płynnym tekstem"11. Nie był jeszcze natomiast tekstem społecznie nośnym. Ta sytuacja zaczęła się zmieniać niemal dziesięć lat po śmierci poety (1998), kiedy to publiczny dyskurs o "żołnierzach wyklętych" znalazł w Wilkach Herberta jeden ze swych najbardziej rozpoznawalnych, najczęściej reprodukowanych znaków.

Przypomnijmy tę dynamikę: zainteresowanie zbrojnym podziemiem antykomunistycznym okresu powojennego, zaznaczające się w pierwszej dekadzie III RP, zaczęło przybierać na sile i zmieniać charakter około 2010 roku. Upamiętnienie irredenty lat 1945-1953 uznano wówczas za zadanie instytucji państwowych $^{12}$. Po prezydenckich i parlamentarnych wyborach 2015 roku temat został już centralnie usytuowany w polityce historycznej nowego obozu rządzącego. Praktyki oraz dyskursy upamiętniające i gloryfikujące „żołnierzy wyklętych" (nazwa ta „wygrała" ze sformułowaniami bardziej ascetycznymi emocjonalnie i stylistycznie, takimi jak „druga konspiracja”) przyjęły formę państwowych i kościelnych ceremonii (także funeralnych), działań edukacyjno-wychowawczych, przekazów medialnych oraz kulturowych i popkulturowych symbolizacji. Właśnie ta dynamika społecznej, medialnej nośności

11 J. Bryant The Fluid Text. A Theory of Revision and Editing for Book and Screen, University of Michigan Press, Ann Arbor 2002.

W roku 2010 prezydent Lech Kaczyński wystąpił z inicjatywą ustawodawczą, zmierzającą do ustanowienia państwowego święta pod nazwą Narodowy Dzień Pamięci „Żołnierzy Wyklętych". Inicjatywa została podtrzymana przez prezydenta Bronisława Komorowskiego. Po otrzymaniu pozytywnej rekomendacji rządu koalicji PO i PSL ustawa została przyjęta przez Sejm i Senat. 
historycznego tematu określiła recepcję Wilków w ostatnich latach. Tekst wprawiony został w ruch, który można metaforyzować za pomocą pojęć laboratoryjno-technicznych (cyrkulacja, recyrkulacja) czy ekonomiczno-rynkowych (dystrybucja, redystrybucja).

W ciągu mijającej dekady Wilki były (i nadal są) reprodukowane przez najróżniejsze witryny internetowe ${ }^{13}$. Wilki były (i nadal są) śpiewane na rozmaite melodie i przez rozmaitych wykonawców, zarówno profesjonalnych, jak i amatorskich, często z okazji Narodowego Dnia Żołnierzy Wyklętych ${ }^{14}$. Wilki były (i nadal są) cytowane w przemówieniach wygłaszanych na uroczystościach wiążących się z tematem, żołnierzy wyklętych"15. Wilki były (i nadal są) wskazywane jako inspiracja symbolicznych akcji wykonywanych w przestrzeni publicznej ${ }^{16}$. Wilki materializują się w formie symbolicznych obiektów

13 Seria przykładów: http://fundacjapamietamy.pl/component/content/article/55-teksty-utworow?start=14 (dostęp 14.12.2020) - strona Fundacji „Pamiętamy”, określającej - w roku 2009 - swój cel jako „przywrócenie pamięci społecznej o ludziach, którzy w drugiej połowie lat 40tych i na początku 50-tych ubiegłego stulecia podjęli walkę zbrojną z komunistami"; https:// www.radom.lasy.gov.pl/aktualnosci/-/asset_publisher/1M8a/content/bieg-tropem-wilczym-w-puszczy-kozienickiej/pop_up (dostęp 14.12.2020) - strona Regionalnej Dyrekcji Lasów Państwowych w Radomiu, post z 26.02.2017 dotyczący organizacji biegu "Tropem Wilczym", upamiętniającego „żołnierzy wyklętych"; https://www.facebook.com/PolonijnaAgencjalnformacyjna/posts/393773701199875/ (dostęp 14.12.2020) - profil FB Polonijnej Agencji Informacyjnej, post z 3.03.2019, wierszowi towarzyszą nagranie jego recytacji oraz impresja filmowa; https://muzeum-ak.pl/cogdziekiedy/konspiracja-niepodleglosciowa-w-skale-i-okolicy-po1945-roku-wystawa/ (dostęp 14.12.2020) - strona Muzeum AK w Krakowie, cytat z wiersza jako motto wystawy "Konspiracja niepodległościowa w Skale i okolicy po 1945 roku”; http://www. podegrodzie.pl/pl/520/3000/dzien-pamieci-\%E2\%80\%9Ezolnierzy-wykletych-w-szkolepodstawowej-w-brzeznej.html (dostęp 14.12.2020) - strona szkoły podstawowej, fragment wiersza jako motto szkolnych obchodów Dnia Żołnierzy Wyklętych; https://niezlomni.com/ zbigniew-herbert-wilki-piekny-hold-zolnierzom-wykletym-wideo/ (dostęp 14.12.2020) - prawicowy portal publicystyczny Niezlomni.com; http://www.fanklubcichociemni.pl/ (dostęp 14.12.2020) - strona fanowska poświęcona serialowi Czas honoru.

Pierwszym wykonawcą śpiewającym Wilki był bodaj Przemysław Gintrowski (płyta Tren, 2008). Przykłady innych wykonań (od piosenki „bardowskiej” do rocka czy rapu) odnaleźć można na serwisie YouTube.

Cytaty z Wilków odnaleźć można w wystąpieniach Prezydenta RP Andrzeja Dudy (https://twitter.com/tvp_info/status/1234038531091259392 (dostęp 14.12.2020)) czy przemówieniu sejmowym posłanki Beaty Strzałki(https://www.sejm.gov.pl/Sejmg.nsf/wypowiedz.xsp?posiedzenie=6\&dzien=1\&wyp=43\&symbol=RWYSTAPIENIA_WYP\&id=361 (dostęp 14.12.2020)). Herberta. 
wpisywanych w tekst miasta, takich jak gdański mural poświęcony m.in. postaciom „Eupaszki” i,Inki”, nie tylko noszący tytuł Wilki, nie tylko wizualizujący wilczą metaforę (obrazowe przedstawienia wilków), lecz także zawierający tekst liryku. Wilki wreszcie podlegają komercjalizacji. Jeśli na produkcie o nazwie handlowej „Body dziecięce Żołnierze Wyklęci” (czyli na śpioszkach dla niemowląt) pojawia się (jak głosi oficjalny opis produktu) „pół twarzy żołnierza, pół pyska wilka", jeśli, równocześnie, dystrybutor tegoż produktu stwierdza, że (pisownia oryginalna!) ,Jest to nasza interpretacja wierszu Wilki Zbigniewa Herberta", to Wilki stają się równocześnie: towarem (sprzedawana jest specyficzna konkretyzacja centralnej metafory liryku) i reklamą towaru (autorytet wiersza ma uwiarygodniać produkt jako "patriotyczny") ${ }^{\mathbf{1 7}}$.

Proces dystrybucji tekstu jest procesem wielotorowym i, jak twierdzę, $\mathrm{w}$ istotnej mierze samonapędzającym się i samosterowalnym. Nie ma centrum zarządzania popularnością Wilków - jeśli utwór krąży po zdecentralizowanej sieci „dyskursu o wyklętych" (której węzłami są publikacje papierowe i internetowe, materialne symbole, wydarzenia etc.), to nie dlatego, że krążenie podtrzymywane jest przez jedną, dającą się wyodrębnić siłę. Nie potrafię wskazać pierwszego, archetypicznego zacytowania Wilków, które wprawiło w ruch serię późniejszych cytacji, jakiejś internetowej witryny-matki (która inspirowałaby swoje nieprzeliczone potomstwo), słowem jakiejś archeprezentacji, która uczyniła Wilki tekstem emblematycznym. Wilki po prostu cyrkulują w społeczno-kulturowym obiegu - splątanym, wieloprzewodowym, pełnym przełączek - i wszystko, co możemy zrobić jako badacze „kulturowej historii wiersza", to przyglądać się samej tej cyrkulacji. I pytać o jej działanie.

Pytanie to daje się sformułować na dwa sposoby. Mogę spytać: co robi wiersz Herberta, wprawiony w ruch cyrkulacji? I odpowiedzieć: cyrkulujący wiersz uczestniczy w procesie konstruowania form zbiorowej pamięci o zbrojnym podziemiu antykomunistycznym. Ale mogę też spytać inaczej: co robi cyrkulacja społeczna z wierszem Herberta? I stosownie do tak sformułowanego pytania zbudować odpowiedź: poddany cyrkulacji wiersz jest używany do konstruowania form zbiorowej pamięci o zbrojnym podziemiu antykomunistycznym. Wybór między usytuowaniem tekstu na pozycji gramatycznego podmiotu lub dopełnienia nie jest tylko kwestią stylistycznych preferencji, lecz wiąże się z opowiedzeniem za wizją aktywnego bądź biernego tekstu-w-kulturze pamięci.

17 https://grafikapatriotyczna.pl/pl/p/Body-dzieciece-Zolnierze-Wykleci/8o8 (dostęp 14.12.2020). 
Pamięciotwórczą aktywność tekstu silnie podkreśla Astrid Erll. Niemiecka badaczka sięga do słownika czasownikowego: literatura „działa” jako „medium gromadzące i ponownie łączące w jednej przestrzeni zróżnicowane sposoby mówienia o przeszłości”, utwory literackie „konstruują wersje przeszłości”, a zarazem „sprawiają, że proces ich konstruowania staje się możliwy do zaobserwowania, przez co może zostać poddany krytyce"18.,,Działa”,,,konstruują",,sprawiają" - wszystkie te czasowniki eksponują performatywną moc podmiotu. Erll wiąże sprawczą zdolność literatury ze specyficznymi trybami użycia języka, mówiąc o „potencjalnej sile pamięciowej (lub wpływie) form literackich"19 $\mathrm{Za}$ pewne w takim właśnie rejestrze - czasownikowym, aktywistycznym - można komentować społeczny rezonans Herbertowskich Wilków, zwracając uwagę na ich potencjał afektywny, sugestywność metafory, rytmiczną energię frazy.

Można teżjednak twierdzić inaczej. Przyczyna społeczno-medialnej nośności Wilków leży poza poetyką i retoryką, w czymś wobec tekstu zewnętrznym: w uprzednim autorytecie poety oraz w silnym zapotrzebowaniu na teksty i obrazy pozwalające mówić o „wyklętych”. Wilki zyskały w omawianym tu dyskursie pozycję toposu nie ze względu na to, jak napisał je Herbert, lecz ze względu na to, ż e napisał je Herbert. Przede wszystkim zaś dlatego, $\dot{z}$ e już były napis ane, znajdowały się we właściwym czasie i miejscu, gotowe do użycia przez rodzącą się praktykę organizowania pamięci, która po prostu je zastała i spożytkowała.

Argumentu przemawiającego za optyką drugą - wiersz nie jako agens, lecz jako bierny instrument działań - dostarczyć może obserwacja: sam tekst Wilków okazuje się w społecznej recepcji elementem zaskakująco bezbronnym. Im skuteczniej jest dystrybuowany, tym mocniej bywa odkształcany. Bezbronność tekstu i swoista „przemocowość" mechanizmów kulturowej dystrybucji ujawniają się w procesie reprodukcji wiersza online. Wirtualna proliferacja tekstu musiała do tego doprowadzić: gdzieś, w jakimś węźle sieci, po raz pierwszy Wilki pojawiły się w postaci zniekształconej. Wers „przegrali dom swój w białym borze” został zastąpiony banalnym „przegrali bój we własnym domu”; zamiast dramatycznej formuły „nie nam żałować gryzipiórkom” zjawiła się formuła „Nie było komu z łap wyjmować cierni”, niezgrabna, rozbijająca metryczną strukturę tekstu. Wreszcie zamiast finałowego „został na zawsze w dobrym śniegu / żółtawy mocz i ten trop wilczy” wkradła

18 A. Erll Kultura pamięci. Wprowadzenie, przeł. A. Teperek, Wydawnictwa Uniwersytetu Warszawskiego, Warszawa 2018, s. 234. 
się wersja „ich gniew ich rozpacz ich ślad wilczy”. Skutki tego edytorskiego grzechu pierworodnego okazały się trwałe: $\mathrm{w}$ świecie nieograniczonej reprodukcji, rządzonej omnipotentnym gestem Ctrl + C, ,fejkowe” Wilki skutecznie jęły wypierać oryginal ${ }^{20}$. Zjawisko to nie ogranicza się do świata wirtualnego, lecz przenika do podpiętego pod internet „realu”: cytaty z „fejkowych” Wilków pojawiają się w wystąpieniach publicznych ${ }^{21}$.

Łatwość, z jaką fałszywe Wilki podszyły się pod Wilki prawdziwe, tłumaczy się dynamiką samoreprodukującego się niechlujstwa charakterystyczną dla funkcjonowania tekstów literackich w sieci. Wydaje się jednak, że zniekształcenie, jakiemu uległ tekst w procesie dystrybucji, jest też - do pewnego stopnia - efektem działania mechanizmów obronnych wytwarzanych przez kulturę pamięci. „Emendacje” wykonane na tekście usunęły z niego element, który zakłócał tradycyjnie pojmowaną wzniosłość aktu upamiętnienia: frazę mówiącą o "żółtawym moczu" jako jedynym śladzie, pozostawionym przez tytułowe „wilki”. Być może u źródeł tej podmiany (następnie reprodukowanej już bezwiednie i bezrefleksyjnie) tkwiło przeświadczenie jakiegoś czytelnika-użytkownika tekstu, że motyw obsceniczny narusza patriotyczno-funeralne dekorum. „Ich gniew, ich rozpacz, ich ślad wilczy” - jako cytat w wystąpieniu na ważnej uroczystości fraza ta brzmi „lepiej” niż „żółtawy mocz i ten trop wilczy". Trwający mimo upływu lat "gniew” bojowników jest bardziej wzniosły od "moczu”. A liczba sylab - nie ulega zmianie...

Czy więc to wiersz posiada retoryczne "tryby pamięci” wytwarzające kulturę upamiętnienia, czy raczej tryby medialnych „urządzeń do pamiętania" mielą, przykrawają wiersz ${ }^{22}$ ? Skłaniałbym się do twierdzenia, że status wiersza jest przechodni: między stroną czynną a stroną bierną, między pozycją

20 Na co najmniej kilkunastu stronach internetowych zachodzi ta - sądząc po zamieszczanych komentarzach, czasem zauważalna, czasem zaś niewidoczna dla czytelników - podmiana (http://naszsalon24.org/2018/03/06/herber-i-wilki/ (dostęp 14.12.2020) - tu dyskusja użytkowników portalu na temat poprawnej wersji). Wśród stron powielających zniekształcony tekst znajduje się strona literackiej nagrody "Silesius": http://silesius.wroclaw.pl/2016/03/o1/zbigniew-herbert-wilki/ (dostęp 14.12.2020). M.in. w krótkim, improwizowanym wystąpieniu Prezydenta RP Andrzeja Dudy (por. przyp. 15).

Pojęcie "urządzenia do pamiętania” zostało wprowadzone przez Marię Kobielską, zob. tejże Urządzenia do pamiętania. W precyzyjnym i teoretycznie wyrafinowanym ujęciu Kobielskiej pojęcie to oznacza, najogólniej mówiąc „ "coś”, co wytwarza określone wzorce i praktyki pamiętania. Urządzeniem do pamiętania może być i całokształt dyskursu o żołnierzach wyklętych (byłoby to, jak powiada Kobielska, urządzenie wieloelementowe), i koszulka z wizerunkiem wilka oraz hasłem wynotowanym z wiersza Herberta (w terminologii Kobielskiej: mikrourządzenie). 
podmiotu a pozycją przedmiotu. Ambiwalentnie kształtuje się też odpowiedź na pytanie fundamentalne: o to, czy wiersz rzeczywiście służy temu, czemu chciał służyć, to znaczy budowaniu formuły pamięci o konkretnym wycinku przeszłości. Bo niewątpliwie taka miała być jego rola: jeśli u progu lat 90. XX wieku ogłaszał on, że „historia głucho milczy”, to dążył tym samym do zastąpienia milczenia mową. Z perspektywy roku 2020 sukces tej operacji jest dyskusyjny. Mówienie o powojennej irredencie stało się donośne, rodzi się jednak pytanie, w jakim stopniu prowadzi ono do anamnezy rozumianej jako konfrontowanie nas, uczestników teraźniejszości, z przeszłością, w jakim zaś do budowania symulakrów przeszłości, zarazem uniemożliwiających ujawnienie się rzeczywistego (choćby w formie nieuchronnie szczątkowej, śladowej) i pozorujących (nie zawsze ze świadomością pozorowania) pojawienie się rzeczywistego ${ }^{23}$. Której tendencji służą Wilki bardziej, częściej? Bilansująca odpowiedź na tak postawione pytanie jest trudna - koniec końców, będziemy zawsze docierać do konkretnych przejawów „kultury pamięci” i dokonywać ich oceniających interpretacji.

Tak czy inaczej, dzisiejszy dyskurs o „żołnierzach wyklętych” wpisuje się w pole wciąż w Polsce narastających sporów, pretensji i konfliktów o bardzo wysokiej temperaturze emocjonalnej. Jest wykorzystywany do politycznych działań ofensywnych ${ }^{24}$ i sam staje się przedmiotem operacji zaczepnych. W rezultacie atakowany bywa także jego liryczny emblemat. Gdański mural, będący materializacją tekstu wiersza, został wiosną 2017 roku (niespełna rok po odsłonięciu) uszkodzony przez anonimowego sprawcę. Bezpośrednim obiektem agresji nie był tekst Herberta - słowo „morderca” wypisano czerwoną farbą nie na żadnym z Herbertowskich wersów, lecz na wizerunku majora Szendzielarza „Łupaszki”, co wiązało się z publicznie rozpatrywanymi kontrowersjami dotyczącymi działalności partyzanta ${ }^{25}$. Przedmiotem ataku

Obawa, że spełnia się ów drugi scenariusz, artykułowana jest w publicystyce społeczno-historycznej, nie tylko w jej nurcie "lewicowym" (por. ). Majmurek Od kultu "wyklętych" do przemocy, https://krytykapolityczna.pl/kraj/od-kultu-wykletych-do-przemocy/ (dostęp 14.12.2020)), lecz także, rzadziej, w nurcie centroprawicowym (por. P. Kaszczyszyn Więcej niż Wyklęci, https:// klubjagiellonski.pl/2017/03/01/wiecej-niz-wykleci/ (dostęp 14.12.2020)).

Operowanie cytatem „historia o nich głucho milczy” w przemówieniach polityków czy sympatyków obozu sprawującego od 2015 roku władzę wiąże się często z komentarzem przypisującym winę niepamiętania nie tylko komunistycznemu państwu, lecz także "III RP" (jej "elitom", "mediom" etc.).

25 Na temat sporu o "Łupaszkę" (w tym o jego rolę w pacyfikacji litewskiej wsi Dubinki w 1944 roku, będącej akcją odwetową za pacyfikację polskiej wsi przez oddziały litewskie) zob. m.in. 
była jednak pośrednio wizualno-tekstowa całość; tym samym wiersz Herberta znalazł się w polu symbolicznej wojny, która rychło przeniosła się z muralu na internetowe fora. Innym przykładem, ataku symbolicznego" - tym razem już bezpośredniego - jest parodia Wilków opublikowana w roku 2018 przez Jasia Kapelę. Pisząc wiersz Nie dla nich, wyśmiewający współczesną opowieść o „żołnierzach wyklętych”, Kapela, za wierszem Herberta, wprowadził podział na czterowersowe strofy rymowane abab, utrzymał czterostopowy jamb z hiperkataleksą w klauzuli i zastosował figurę wyliczania niespełnionych pragnień zabitych. O ile jednak kompozycyjno-prozodyjne parametry Wilków powtórzone zostały bez karykaturalnego przerysowania, o tyle wyliczenie pragnień i niespełnień zostało już sprowadzone ad absurdum ${ }^{26}$. Dewastację obiektu zawierającego tekst wiersza (2017) oraz parodię samego utworu (2018) określić można wspólnym mianem „politycznego semioklazmu” czy "tekstoklazmu" - tekst jest tu niszczony jako znak, którym posługuje się negowana polityka pamięci.

\section{Zanim!}

Zanim! Teraz ten spójnik staje się dla mnie kluczowy. Zanim Wilki zostały sparodiowane, zanim zmaterializowały się jako mural oraz jako niemowlęce śpioszki, zanim stały się sztandarowym tekstem rytuału upamiętnienia, zanim rozsiały się (i przeinaczyły) na niezliczonych witrynach, zanim trafiły do tomiku i na rozkładówkę czasopisma, zanim ktokolwiek, poza autorem, zobaczył ten utwór w jakimkolwiek bądź zapisie - trwała już wibrująca historia tekstu. Ta historia jest także historią do opowiedzenia - nie tylko w kategoriach krytyki genetycznej (którą perspektywa „zanim” interesuje ex professo), lecz także w kategoriach pamięcioznawstwa ${ }^{27}$.

Dossier genezy Herbertowskich Wilków składa się z materiałów zdeponowanych w Archiwum Zbigniewa Herberta (Biblioteka Narodowa

P. Rokicki Glinciszki i Dubinki. Zbrodnie wojenne na Wileńszczyźnie w połowie 1944 roku i ich konsekwencje we współczesnych relacjach polsko-litewskich, IPN, Warszawa 2015.

https://krytykapolityczna.pl/felietony/jas-kapela/troll-wyklety/ (dostęp 14.12.2020).

Uwagi pomieszczone w trzeciej części szkicu prezentowałem w formie referatu na konferencji "Doświadczenie archiwum: pismo, ciało, pamięć", która odbyła się na Uniwersytecie Śląskim w Katowicach 6-8.12.2017 roku. W międzyczasie ukazała się biografia Herberta autorstwa Andrzeja Franaszka, w której poruszona została - na prawach krótkiej wzmianki - kwestia brulionowej historii Wilków; zob. A. Franaszek Herbert. Biografia, t. 2: Pan Cogito, Znak, Kraków 2018, s. 766 . 
w Warszawie). Ułożenie ich w sekwencję chronologiczną i funkcjonalnie powiązaną (czyli, mówiąc językiem krytyki genetycznej: przekształcenie dossier w jego dyskursywną reprezentację i interpretację, tak zwany przedtekst) nie jest zadaniem prostym; ostatecznie, wszystko, co możemy wypracować, ma status hipotezy.

Oto sekwencja genezy rozpisana w prawdopodobnym układzie chronologicznym:

- Rękopis 1 (zapis w notatniku, brulion; niedatowany, data powstania prawdopodobnie bardzo zbliżona do daty rękopisu 2; akc. 17 955, t. 141, s. 29v-30);

- Rękopis 2 (zapis w notatniku, brulion, datowany ręką poety na 27 sierpnia 1990 r.; akc. 17 955, t. 141, s. 30);

- Rękopis 3 (luźna kartka, zapis bliski czystopisowi, z nielicznymi skreśleniami i dopiskami, niedatowany; akc. 17 848, t. 1, s. 74);

- Maszynopis 1 (w kilku kopiach, z modyfikacjami odręcznymi, autorskimi oraz, być może również, nieautorskimi, niedatowany; akc. 17 848, t. 1 , s. 76-78);

- Pierwodruk prasowy - marzec 1991;

- Rękopis 4 (luźna kartka, zapis bliski czystopisowi, z nielicznymi skreśleniami i dopiskami; datowany ręką poety na 1 listopad 1991 r.; akc. 17848 , t. 1, s. 75);

- Maszynopis 2 (w kilku kopiach niedatowanych; akc. 17 848,t.1, s. 79-82);

- Publikacja w tomie Rovigo - maj 1992.

Nowo powstający wiersz od najwcześniejszego brulionu był ustabilizowany pod względem genologiczno-tematycznym (tren - wspomnienie o poległych), figuratywnym i tropologicznym (metafora wilcza wprowadzona od razu w tytule i w pierwszym wersie, dalej konsekwentnie podtrzymywana, nigdzie niepodawana w wątpliwość), wersyfikacyjnym (od pierwszego wersu miarą tekstu, w żadnym momencie niezagrożoną przez jakikolwiek konkurencyjny paradygmat, jest jamb) oraz stroficznym (od początku tekst formuje się w strofy czterowersowe, rymowane abab). Dramaturgia tej tekstotwórczej akcji jest właściwie niewielka, brakuje tego, co dla genetyka najbardziej spektakularne (i co zdarza się w niektórych brulionach Herberta $^{28}$ ): poniechanych

28 Zob. Pracownia Herberta. Studia nad procesem tekstotwórczym, red. M. Antoniuk, Wydawnictwo Uniwersytetu Jagiellońskiego, Kraków 2017. 
dróg, które mogły prowadzić tekst - i w jakimś momencie faktycznie go prowadziły - ku innym niż „finalny” sensom, zarzuconych możliwości prześwitujących spod skreśleń czy nadpisań, a kumulujących potencjał subwersywny wobec „ostatecznego", ,zwycięskiego" samorozumienia tekstu.

To nie są szczególnie fascynujące bruliony... jeśli patrzymy tylko na ich centrum, na przestrzeń rozpiętą między tytułem a ostatnim wersem. To, co najciekawsze w perspektywie krytycznogenetycznej - i najważniejsze w perspektywie pamięcioznawczej - rozgrywa się powyżej głównego kadru, w prawym górnym rogu większości dokumentów. Poniższa transliteracja topograficzna (czyli odzwierciedlająca przestrzenność inskrypcji) ${ }^{29}$ przedstawia zapis dedykacji w rękopisie 1:

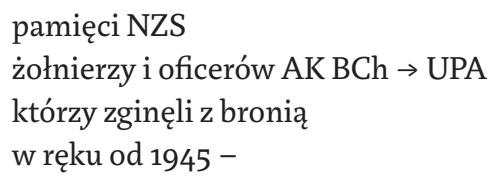

54

Dzięki analizie formy zapisu, w historii jego przyrastania wyodrębnić da się trzy stadia, co wizualizuje poniższa transliteracja dynamiczna (czcionką pogrubioną oznaczono każdorazowo element nowy, dodany w danym stadium).

$\begin{array}{lll}\text { Stadium I } & \text { Stadium II } & \text { Stadium III } \\ \text { pamięci } & \text { pamięci NZS } & \text { pamięci NZS } \\ \text { żołnierzy i oficerów AK } & \text { żołnierzy i oficerów AK } & \text { żołnierzy i oficerów AK } \\ \text { BCh } & \text { BCh } & \text { BCh } \rightarrow \text { UPA } \\ \text { którzy zginęli z bronią } & \text { którzy zginęli z bronią } & \text { którzy zginęli z bronią } \\ \text { w ręku od 1945 - } & \text { w ręku od 1945 - } & \text { w ręku od 1945 - } \\ \mathbf{5 4} & 54 & 54\end{array}$

Kształt pierwszej wersji dedykacji (zarówno graficzny, jak i ideowy) wyłaniał się stopniowo, na sposób addytywny: najpierw zarysowane zostało centrum pamięci, ,zajęte” przez Armię Krajową (czyli największą, ale też najbardziej heterogeniczną - pod względem społecznym, politycznym, ideowym

29 Zob. M. Troszyński Alchemia rękopisu. "Samuel Zborowski" Juliusza Słowackiego, Wydawnictwo IBL, Warszawa 2017, s. 37-43. 
- formację podziemną) oraz przez Bataliony Chłopskie (czyli organizację związaną z podziemnym ruchem ludowym). Potem dopiero w pole upamiętnienia włączone zostają Narodowe Siły Zbrojne (omyłkowo oznaczone skrótem NZS - przestawka bardzo typowa dla Herberta, skryptora często popełniającego literówki), czyli prawe, nacjonalistyczne skrzydło polskiego podziemia niepodległościowego, na koniec zaś wprowadzona zostaje w tę przestrzeń Ukraińska Powstańcza Armia.

Ten sam model addycji i inkluzji rządzi kształtowaniem dedykacji w drugim, brulionowym rzucie wiersza. W transliteracji czcionką zwykłą oznaczono zapis sporządzony czarnym pisakiem, czcionką pogrubioną - niewątpliwie od niego późniejszy zapis wykonany pisakiem fioletowym.

\section{ŻOB}

Pamięci żołnierzy i oficerów

WiN A.K. BiCh WiN NSZ UPA

tzw. Własowców którzy zginęli z bronią w ręce

i nie złamali przysięgi

w latach 1944-1954

Tym razem centrum pamięci obejmuje wszystkie formacje, wymienione w ostatniej, najpełniejszej wersji „dedykacji pierwszej” (AK, BCh, NZS iUPA), do centrum tego, już w pierwszym zapisie, dodana też zostaje Wolność i Niezawiłość (WiN), potem zaś, w zapisie drugim, innym kolorem dodano: Wolność i Niezawisłość (zdublowanie, kolejny przejaw roztargnienia poety), Żydowską Organizację Bojową (ŻOB) i własowców.

Brulion nr 2 nie domyka przekształceń dedykacji. Każdy kolejny dokument procesu twórczego wprowadza jakiś nowy jej wariant: Herbert nie dodaje nowych skrótowców, lecz testuje kombinacje w obrębie pola wyboru.

Rękopis 3: „Pamięci żołnierzy i oficerów którzy zginęli z bronią w ręku i nie złamali przysięgi" [dopisane nad tym: wszystkich formacji]

Maszynopis 1 (liczne kopie): „Pamięci żołnierzy i oficerów AK BCh WiN NSZ UPA i Własowcom, którzy zginęli z bronią w ręce i nie złamali przysięgi".

Maszynopis 1 - jedna z kopii: do powyższej dedykacji Herbert dopisał ręcznie „ŻOB”;

Maszynopis 1 - inna kopia: u dołu strony ręcznie dopisana alternatywna wersja dedykacji „Pamięci Oficerów Podoficerów żołnierzy którzy zginęli w lasach po roku 945 z bronią w ręku i nie złamali przysięgi"; 
Pierwodruk w gazecie: „Pamięci Oficerów, Podoficerów, Żołnierzy, którzy zginęli w lasach po roku 1945 z bronią w ręku i nie złamali przysięgi”;

Rękopis 4 oraz maszynopis 2 (hipotetyczne ogniwa pośrednie w pracy nad tekstem po pierwodruku) - brak dedykacji;

Druk tomikowy: „Marii Oberc”.

Dwa podstawowe działania wykonywane w toku pracy to zatem dodawanie nowych pozycji (i w konsekwencji komplikowanie dedykacji jako znaczącej całości), z drugiej zaś redukowanie, usuwanie pozycji (i w konsekwencji upraszczanie dedykacji jako znaczącej całości). Próby uregulowania historycznej referencji tekstu odbywają się między dwoma biegunami, listą pełną (oto jej poziom maksimum osiągnięty w rękopisie 2, następnie „utracony" i ponownie na chwilę „odzyskany" w jednej z kopii maszynopisu 1: AK, BCh, WiN, NSZ, UPA, ŻOB, własowcy) i listą pustą, czyli brakiem dedykacji (rękopis 4, maszynopis 2).

Co to wszystko właściwie znaczy? Oto moja propozycja odpowiedzi: na kolejnych kartach odbywa się proces kształtowania koncyliacyjnej formuły pamięci. Poeta testuje czy symuluje granice tego, co przez wiersz ma być przypominane, co zaś zapomniane (żadna z wersji nie zawiera np. skrótu AL, choć przecież formacja ta uczestniczyła chociażby w powstaniu warszawskim). Zadanie jest karkołomne.

Po pierwsze, zestawiane są polskie jednostki partyzanckie, różne pod względem społecznej proweniencji, politycznych i ideowych orientacji, na tym tle nieraz poważnie skonfliktowane $e^{30}$.

Po drugie, w polu dedykacji sąsiadują niepodległościowe tradycje polskie i ukraińskie, bez wątpienia zantagonizowane, posiadające wzajemnie wykluczające się cele.

Po trzecie, dedykacja usiłuje usytuować we wspólnym polu upamiętnienia Żydowską Organizację Bojową i tzw. własowców. Pomijając już fakt historycznej nieprecyzyjności tego drugiego określenia, problemem jest zestawienie

30 Por. wydany przez IPN Atlas podziemia niepodległościowego 1944-1956, Warszawa 2007, s. XXVI: „Na skutek różnic programowych, odmiennej oceny sytuacji międzynarodowej oraz rywalizacji o wpływy wśród ludności w niektórych regionach dochodziło do konfliktu pomiędzy podziemiem akowsko-winowskim a konspiracją narodową. Lokalnie, na Białostocczyźnie, zdarzały się przypadki wzajemnych likwidacji". Konflikty, w skrajnych przypadkach przekładające się na działania zbrojne, miały też miejsce w 1944 roku między dwoma odłamami NSZ, z których jeden uznawał formalne scalenie z AK, drugi był mu natomiast przeciwny, por. J. Ślaski Polska walczaca, Instytut Wydawniczy Pax, Warszawa 1999, t. 3, s. 1260-1261. 
żołnierzy żydowskich, podejmujących opór wobec Holocaustu zorganizowanego przez niemieckie państwo, i żołnierzy, którzy walczyli u boku niemieckiej armii.

Po czwarte, jedynym właściwie spoiwem „ideowym” dedykacji jest walka wyróżnionych formacji z państwem sowieckim, co faktycznie da się odnieść do AK, BCh, NSZ, WiN, UPA, także do własowców, ale przecież już nie do ŻOB, działającej w innych realiach, mającej innego przeciwnika.

Po piąte, część polskiego i ukraińskiego podziemia niepodległościowego wykazywała postawy antysemickie, często skrajne w swej formie ${ }^{31}$.

Po szóste, w całym przebiegu akcji tekstotwórczej utrzymuje się zasadnicze napięcie między (i tak wewnętrznie popękanym) paratekstem dedykacji a (znacznie bardziej koherentnym wewnętrznie) tekstem wiersza. Paratekst raz po raz wyprowadza referencję poza doświadczenie polskie, podczas gdy tekst utrzymuje się w polonocentryzmie czy w „polono-wyłączności”: wymienione w wierszu pseudonimy są polskie, pochodzą z typowego repertuaru podziemnych polskich pseudonimów - „Ciemny”,,,Świt”,,,Grom"32.

Wymieniam tu „rozsadniki” dedykacji, mając świadomość, że analogicznie można identyfikować jej konektory ${ }^{33}$. Sądzę, że właśnie gra obu tych tendencji - odśrodkowej i dośrodkowej - tłumaczy tak długą autorską pracę nad Wilkami. Problemem odraczającym zakończenie procesu tekstotwórczego nie był kłopot z poziomu konstrukcji tekstu, lecz wypracowanie spójnej „polityki pamięci". Wiersz, który chciał upamiętniać, który miał już gotowe wszystkie retoryczne struktury upamiętnienia, nie mógł się zdecydować, co i kogo chce upamiętnić. Wyobraźmy sobie, że liryk ukazuje się z „maksymalnie pojemną”

Zob. Sz. Rudnicki Moga żyć, byle nie u nas... Propaganda NSZ wobec Żydów, "Więż" 2006 nr 4. Przedmiotem sporów na terenie historiografii i publicystyki historycznej pozostaje kwestia motywacji oraz skali zjawiska fizycznych napaści i mordów dokonywanych na Żydach przez grupy zbrojne (np. w debacie o działalności Józefa „Ognia" Kurasia punktem zapalnym pozostaje sprawa zabójstw na tle antysemickim oraz kwestia odpowiedzialności samego dowódcy). Por. także J. Tokarska-Bakir Terror w Przedborzu, noc z 26/27 maja 1945, https://www.academia. edu/40117272/Terror_W_Przedborzu_noc_z_26_27_maja_1945 (dostęp 14.12.2020).

Na przykład w taki sposób: wiersz dedykowany jest „żołnierzom”, a przynależność konkretnego człowieka do tej lub innej formacji zbrojnej niekoniecznie wiązała się z jego osobistymi preferencjami polityczno-światopoglądowymi, bywała dziełem przypadku. Między polskim a żydowskim podziemiem zbrojnym istniała również współpraca, podobnie jak między partyzantką polską i ukraińską; por. G. Motyka, R. Wnuk "Pany" i „rezuny". Współpraca AK-DSZ-WiN iUPA w latach 1945-1947, Oficyna Wydawnicza Volumen, Warszawa 1997. 
wersją dedykacji w 1991 roku. Prawdopodobnie dla wielu czytelników kamieniem obrazy stałoby się wówczas i zrównanie formacji polskich z UPA (na tle pamięci i postpamięci o wołyńskiej traumie), i odwołanie do „własowców”. Sięgając po tę nazwę, Herbert myślał przypuszczalnie o „własowcach w sensie ścisłym", czyli żołnierzach tzw. ROA, oficjalnie podlegających gen. Własowowi. Jednak w popularnym użyciu społecznym termin "własowcy" był często zbiorczym określeniem wszelkich formacji zbrojnych tworzonych przez hitlerowskie Niemcy, a rekrutujących się spośród Rosjan czy Ukraińców (w tym oddziałów pacyfikujących powstanie warszawskie). Herbert miał chyba jasną świadomość, że pamięć (nie)uwspólniona bywa ładunkiem wybuchowym, i obchodził się z nią z daleko idącą ostrożnością - dlatego, jak sądzę, po serii brulionowych prób zdecydował się na całkowitą rezygnację z operowania nazwami formacji (w obu publikacjach - gazetowej i tomikowej).

Dedykacja długo nie mogła znaleźć formuły. Pozostawała otwarta. Jak otwarta, niedająca się zasklepić i zagoić rana.

\section{W stronę „poietyki (nie)pamięci"}

Z poziomu jednostkowej analizy wracam na poziom teoretycznego uogólnienia, nie z "pustymi rękami” jednak, lecz z zasobem „wypraktykowanego" doświadczenia. Jest to powrót do pytania o możliwe miejsce krytyki genetycznej w polu pamięcioznawstwa. Odpowiedź, którą mogę poddać pod rozwagę, brzmi najogólniej tak. Krytyka genetyczna włączona w zakres studiów pamięcioznawczych pozwala im na szerszy ogląd, na głębsze sondowanie, na bardziej holistyczne i dynamiczne ujęcie tego właśnie, co studia pamięcioznawcze pragną studiować: usytuowania tekstu wewnątrz kultury pamięci oraz realizowania się kultury pamięci poprzez medium tekstu. To usytuowanie i ta realizacja nie sprowadzają się bowiem wyłącznie do fenomenów zauważalnych w polu społecznej widzialności. Przebiegające w ukryciu narodziny „tekstu pamięci” są „pamięcioznawczo ciekawe”, bo już związane z problemami dla pamięcioznawstwa centralnymi, takimi jak konkurowanie różnych obrazów przeszłości, wysiłek artykułowania doświadczeń i ich interpretacji, a także opory, jakie wysiłek ten przełamuje (lub których przełamać nie potrafi). Jeszcze inaczej: krytyka genetyczna może powiększać głębię operacyjną pamięcioznawstwa.

Potencjalny „zwrot genetyczny” w badaniach nad literaturą i pamięcią jest już antycypowany przez dyskurs, którym badania te się posługują. Jedną z jego preferowanych metafor stanowi metafora "negocjowania" $i$,negocjacji”. 
I tak Birgit Neumann stwierdza, że „c o i jak pamiętania stale negocjują z sobą i przeciw sobie, stale stawiają sobie wyzwania, wzywając do zmiany znaczenia" ${ }^{34}$. Astrid Erll powiada z kolei, że funkcją literatury jest prowadzenie „negocjacji konkurencyjnych pamięci”35. Obie metafory pozycjonują tekst jako pośrednika. Ale „negocjowanie” jest pojęciem z jednej strony uwikłanym w procesualność (negocjacje trwają, wymagają czasu, są procesem, w którym coś się zmienia, wypracowuje, jest inne w punkcie wyjścia i dojścia), z drugiej zaś odwołującym się do sfery zakulisowej (negocjujemy w zaciszu, nie zaś publicznie). Otóż oba te ukierunkowania pojęcia „negocjacji” - w stronę procesualności i w stronę skrytości - zachęcają do uwzględnienia perspektywy genetycznej.

„Negocjacje między c o i jak pamiętania” odbywają się ze szczególną intensywnością w brulionowych stadiach pisarstwa autobiograficznego: to właśnie tam zobaczyć można, jak ostateczny kształt autobiografii wyłania się w toku prób, przekształceń, przemieszczeń, którym podlega nie tylko stylistyczna warstwa narracji, lecz także interpretacja biograficznych faktów, a nawet sama faktografia ${ }^{36}$."Negocjowanie konkurencyjnych pamięci” - czyż nie jest to idealna metafora na opisanie tego, co w brulionach Wilków dzieje się z dedykacją? Stronami negocjującymi byłyby w tym ujęciu mówiące różnymi językami symbolicznymi polskie, ukraińskie, rosyjskie, żydowskie pamięci historyczne. Lub inaczej: stroną negocjacji jest tu sam poeta; „fiksując" definitywny kształt dedykacji, uwzględnia on stanowisko tekstu (już w pierwszym brulionie osiągającego swój wydźwięk, z którym paratekst będzie musiał współbrzmieć), własne przeświadczenia historyczne (te zaś mogą być przecież niejednoznaczne i pozostawać w procesie wewnętrznej negocjacji), a także wrażliwość wirtualnego czytelnika, ukształtowaną przez kulturę polskiej pamięci u progu lat 9o. XX wieku.

B. Neumann What Makes Literature Valuable: Fictions ofMeta-Memory and the Ethics of Remembering, w: Ethics in Culture. The Dissemination of Values through Literature and Other Media, ed. A. Erll, H. Grabes, A. Nünning, De Gruyter, Berlin-New York 2008, s. 138; cytat w wersji polskiej podaję za: J. Tabaszewska Od literatury jako medium pamięci do poetyki pamięci. Kategoria pamięci kulturowej w badaniach nad literaturą, "Pamiętnik Literacki” 2013 Z. 4, s. 58.

A. Erll Kultura pamięci..., , s. 224.

Por. pionierskie (na polskim gruncie) ustalenia Olgi Dawidowicz-Chymkowskiej poświęcone autobiograficznej prozie Kuncewiczowej: Przez kreślenie do kreacji. Analiza procesu twórczego zapisanego w brulionach dzieł literackich, Wydawnictwo IBL, Warszawa 2007, s. 115-225. Zob. także P. Rodak Między dziennikiem a literaturq. Dziennik polskiego pisarza w XX wieku, Wydawnictwa Uniwersytetu Warszawskiego, Warszawa 2011. 
Krytyka genetyczna może wypełniać pewną metodologiczną wyrwę w projekcie pamięcioznawstwa. Jeszcze raz wracam do teorii Astrid Erll, której częścią jest pomysłowo skonceptualizowany model, będący, jak to ujmuje badaczka, "delikatną parafrazą" koncepcji „trzech poziomów mimesis" Paula Ricoeura. Model ów wyróżnia "trzy poziomy mimesis w kulturze pamięci". Poziom pierwszy to "prefiguracja tekstu literackiego przez kulturę pamięci", zasób uprzednio istniejących kodów reprezentowania przeszłości, bytujących w innych tekstach kultury, społecznych praktykach upamiętnienia etc., a określających spektrum możliwości pamiętania, wobec którego określa się nowo powstały utwór. Poziom drugi to "konfiguracje literackie”, czyli nowo powstałe utwory, w których "prefigurujące" kody pamiętania są już przesiane, przetworzone, na nowo powiązane w swoiste całości. Jako poziom trzeci wyróżnione zostają „refiguracje zbiorowe”, czyli to, co ze skonfigurowanych w dziele literackim kodów pamięci wyłania się w następstwie społecznego odbioru dzieła. I co z kolei stać się może „prefiguracją” wobec kolejnych, następnych tekstów pamięci - w ten sposób model domyka się, przyjmując formę koła ${ }^{37}$.

Otóż twierdzę, że model Erll zaprasza do współpracy krytykę genetyczną. „Wskazówki, co do schematów medialnych, które mogły prefigurować tekst, znajdziemy, przyglądając się wcześniejszym reprezentacjom medialnym, prezentującym np. podobne wzorce narracyjne i strategie retoryczne" - powiada niemiecka badaczka ${ }^{38}$. Niewątpliwie tak jest. Można jednak zauważyć, że archiwum pisarza - wraz ze zdeponowanymi w nim brulionami, planami utworu, notatkami - może się okazać bardziej bezpośrednią „wskazówką", unaoczniającą prefiguracyjne (stymulacyjne, opresyjne) działanie kultur pamięci. Dalej w całym wywodzie, którym Erll obsługuje swój trójtaktowy model, zauważalne jest pewne stylistyczne napięcie między retoryką spacjalności i statyki („prefiguracja”, ,konfiguracja” i „refiguracja” jako „poziomy" ${ }^{\prime \prime 2}$ ) a retoryką temporalności i dynamiki („konfiguracja to aktywny proces konstrukcyjny" $\left.{ }^{40}\right)$. Wychylenie w stronę tej drugiej tendencji stylistycznej ujawnia ciążenie koncepcji Astrid Erll ku dynamicznym ujęciom problemu. I znów tu właśnie czeka już krytyka genetyczna, wskazując na brulion, czyli

37 Zob. A. Erll Kultura pamięci..., s. 236-242.

38 Tamże, s. 241.

39 Tamże, s. 242, schemat VI.1. 
brakujące ogniwo modelowego łańcucha. Jeśli gdzieś możemy zobaczyć Wilki jako „konfigurację pamięci” - taką jednak, która ma charakter „aktywnego procesu konstrukcyjnego" - to właśnie w tych wszystkich rękopisach i maszynopisach, w których obserwować można na przemian puchnącą i kurczącą się dedykację. Wilki wydrukowane na łamach "Czasu Krakowskiego” są już „konfiguracją pamięci” i wytworem "procesu konstrukcyjnego”; aby uzmysłowić sobie samo „konfigurowanie”, sam „proces konstrukcyjny”, należy poszerzyć pole oglądu o Wilki brulionowe. Jeszcze jeden cytat z Erll: „poziom konfiguracji jest kluczem do zrozumienia roli literatury jako medium pamięci kulturowej. To tutaj dzieła literackie gromadzą, przekształcają i restrukturyzują rzeczywiste i wyobrażone praktyki pamięci i zapominania"41. I jeszcze raz komentarz w tym samym duchu, co poprzednie: owo „tutaj” szczególnie ciekawie konkretyzuje się jako brulion - ze wszystkimi jego skreśleniami, dopiskami na marginesach i w interliniach, z całym tym śladem pracy pamiętania. I pracy zapominania.

Starając się wykazać swoistą kompatybilność krytyczno-genetycznego modus operandi oraz studiów nad „literaturą-i-pamięcią", odwołuję się do prac badaczy niemieckich. Analogiczny wywód warto też jednak przeprowadzić w odniesieniu do oryginalnych, najnowszych prac badaczy polskich. Justyna Tabaszewska sformułowała niedawno ciekawy projekt - jak to ujęła "metadyscypliny", łączącej instrumentaria i języki literaturoznawstwa oraz pamięcioznawstwa i działającej pod nazwą „poetyki pamięci”. Jej zadaniem miałoby być - tu konieczny dłuższy cytat -

wskazanie na to, jakie [...] tryby, modele i funkcje pamięci są przywoływane, jakiedziałania - w obrębie tekstu - podejmuje podmi ot czynności twórczych wobec owych praktyk, na ile są one przypominane, podważane, powtarzane, a na ile można dane rozwiązania artystyczne bądź strukturalne uznać za próby wytworzenia nowych modeli odniesień do pamięci i tradycji [wyróżnienia - M.A.].42

Brzmi to niezwykle ciekawie (i znajduje ciekawą realizację w „praktycznej" części książki Tabaszewskiej). Znów nie mogę jednak oprzeć się wrażeniu, że formuły tu użyte niemal wywołują do tablicy genetykę, którą interesuje „działanie” (a nie tylko „dzieło”), która pragnie zobaczyć „podmiot czynności

41 Tamże.

42 J. Tabaszewska, Od literatury jako medium pamięci..., s. 173. 
twórczych” w akcji i dla której najbardziej ekscytująca jest „próba wytworzenia". Jak sądzę, przykład genetycznej analizy Wilków tego właśnie dowodzi. I zachęca poetykę pamięci, by swoją analizą objęła nie tylko to, co dzieje się „W obrębie tekstu”, lecz również „w obrębie przedtekstu”.

Mam nadzieję, że zdołałem wykazać - choć w pewnej mierze - że pamięcioznawstwo „zorientowane na literaturę” może znaleźć w krytyce genetycznej wartościowego „kooperanta” ${ }^{43}$. I vice versa: że krytyka genetyczna, przez włączenie pamięcioznawczych wątków w zakres swojego praktykowania, zyskuje sposobność ciekawego zaznaczenia własnej pozycji w polu najbardziej dziś aktualnych, nośnych i żywych tendencji światowej humanistyki.

Genetyka pamięcioznawstwem podszyta może na nowo odświeżająco określić stawkę swojej gry. Staje się nią mianowicie przychwycenie inflagranti pamięciotwórczej (ale też „pamięciolikwidacyjnej”) mocy tekstu oraz tekstotwórczej (ale też cenzurującej, blokującej) mocy pamięci.

Innymi słowy, krytyka genetyczna może stać się tym, czym „mianowałem” ją w tytule mojego szkicu: kulturową poietyką (nie)pamięci.

43 Co oczywiście nie oznacza, że krytyka genetyczna zawsze i wszędzie może się ciekawie włączyć w spektrum pamięcioznawstwa. Jeden przykład wymowny: innym, „pamięcioznawczo gorącym" wierszem Herberta, pochodzącym z tego samego okresu co Wilki, są poświęcone zbrodni katyńskiej Guziki. Brulion tego utworu jest interesujący z punktu widzenia krytyki genetycznej. Nie wydaje się jednak, by genetyczna analiza mogła w istotny sposób pogłębić pamięcioznawczą analizę Guzików, przeprowadzoną przez M. Kobielską (zob. Polska kultura pamięci..., S. 129-132). 


\section{Abstract}

\section{Mateusz Antoniuk}

JAGIELLONIAN UNIVERSITY (CRACOW)

Genetic Criticism as a Cultural Poietics of (Non)Memory

Antoniuk begins by proposing that genetic criticism (the study of the process of writing) as a scholarly practice has a potential for effective and valuable collaboration with memory studies. In parts two and three he offers a literary critical and sociological analysis of Zbigniew Herbert's poem "Wilki," which enjoys the status of a memory text. Antoniuk begins by examining its publication history, then demonstrates the effectiveness of genetic criticism which - by revealing the poem's manuscript pre-history - deepens our understanding of it as"a medium of memory". Part four is a methodologial and theoretical extrapolation of the insights gained from the analysis of this unique case.

\section{Keywords}

genetic criticism, memory studies, Zbigniew Herbert, poetry 